\title{
Morphometric Analysis of a Shakkar River Catchment Using RS and GIS
}

\author{
Sarita Gajbhiye \\ Department of WRD \& M, IIT Roorkee (Uttarakhand) \\ gajbhiyesarita@gmail.com
}

\begin{abstract}
Employing Remote Sensing (RS) and Geographical Information System (GIS), morphometric analysis was carried out for Shakkar River catchment (area $=2220 \mathrm{~km} 2)$ using satellite imageries and topographic maps on a scale map of 1:50,000 to determine its drainage characteristics. Exhibiting a dendritic drainage pattern, the drainage density of the study area varies from 2.84 to $3.67 \mathrm{~km} / \mathrm{km}^{2}$ which observed that area is highly permeable and structurally controlled. The bifurcation ratio varies from 3.49 to 5.52 and the elongation ratio vary from 0.47 to 1.00, whereas value nearing 1 are typical of region of low relief. The area is delineated in 8 sub watershed. The morphometric analysis reveals that sub-watershed 3 show lower value of Drainage density and Stream Frequency, Sub-watershed 6 shows low value Compactness Constant and sub-watershed 7 show lower value of Circulatory Ratio and Form factor. The relief aspect lower in the subwatershed 2. And the values of Average slope vary from 9.27 to $88.50 \%$. This study of morphometric analysis characterizes the watershed and helps to understand the hydrological behaviour of the Shakker river catchment.
\end{abstract}

Keywords: Morphometric, sub watershed, Remote Sensing and GIS, Drainage patterns

\section{Introduction}

The watershed management planning highlights the management techniques to control erosion in the catchment/watershed area. Life span of a reservoir in case of a seasonal storage dams is greatly reduced due to soil erosion in the catchment area (Gajbhiye et al., 2014a). Keeping in ever increasing population and need for food security, it is realized that the water and the land resources need to be developed, used and managed in an integrated and comprehensive manner. The spatial resolution remotely sensed data coupled with topographical data analysis procedures have effective tool to understand and manage the natural resources. It provides real time and accurate information related to distinct geological formation, landforms and helps in identification of drainage channel which are altered by natural forces of human activities. The geomorphological parameter directly or indirectly reflects almost the entire watershed based causative factor affecting runoff and sediment loss. Geomorphological analysis provides quantitative description of the basin geometry to understand initial slope or inequalities in the rock hardness, structural controls, recent diatrophism, geological and geomorphic history of drainage basin (Strahler, 1964). In absence of huge hydrological data morphometric parameter of watershed may be helpful in characterizing a watershed as morphological and climatic characteristics of a basin govern a hydrological response to a considerable extent. The morphological characteristic of a basin represents its attributes, which may be employed in synthesizing hydrological response. The importance of morphological factors can not be overlooked in accurate prediction of runoff. Basin characteristics when measured and expressed in quantified morphometric parameters can be studied for the influence on runoff. Hence, linking of the morphologic parameters with the 
hydrological characteristics of the basin can lead to simple and useful procedure to simulate the hydrologic behavior of various basins, particularly the ungauged one. Interpretation and quantitative analysis of various drainage parameters enables qualitative evaluation of surface runoff, infiltration and susceptibility to erosion within the basin. Prioritization and morphometric analysis using remote sensing and GIS techniques have been attempted by number of researchers (Nautiyal,1994; Srivastava et al.,1995; Srivastava, 1997; Nag, 1998; Agarwal,1998; Biswas, et al., 1999; Singh et al., 1997; Sreedevi et al., 2001,2005; Vittala et al., 2004; Reddy et al., 2004; Gajbhiye et al., 2013a,c; Gajbhiye et al., 2014d; Sharma et al., 2014 ) and all have concluded that remote sensing and GIS are powerful tools for studying basin morphometry and continuous monitoring. Considering all these aspects an attempt has been made, using advanced remote sensing and GIS technology to compute basin morphometric characteristics for various parameters.

\section{Study Area}

The Shakkar river rises in the Satpura range, east of the Chhindi village, Chhindwara district, Madhya Pradesh an elevation of about $600 \mathrm{~m}$ at latitude $22^{\circ} 23^{\prime}$ $\mathrm{N}$ longitude $78^{\circ} 52^{\prime} \mathrm{E}$ (Figure 1). The watershed covers $2220 \mathrm{~km}^{2}$ area. The climate of the basin is generally dry except the southwest monsoon season. The southwest monsoon starts from middle of June and lasts till end of September. October and middle of November constitute the post monsoon or retreating monsoon season. The normal annual rainfall is $1192.1 \mathrm{~mm}$. The normal maximum temperature received during the month of May is $42.5^{\circ} \mathrm{C}$ and minimum during the month of January is $8.2^{0}$ C (Gajbhiye et al., 2013b). Soils are mainly clayey to loamy in texture with calcareous concretions invariably present. They are sticky and in summer, due to shrinkage, develop deep cracks. They generally predominate in montmorillonite and beidellite type of clays .In rest of alluvial areas, mixed clays, black to brown to reddish brown, derived from sandstones and traps is observed which is sandy clay in nature with calcareous concretions. Near the banks of the rivers and at the confluence, light yellow to yellowish brown soils are noticed which were deposited during the recent past .These soils are clayey to silt in nature (Mishra et al., 2013; Gajbhiye et al., 2014b,c).

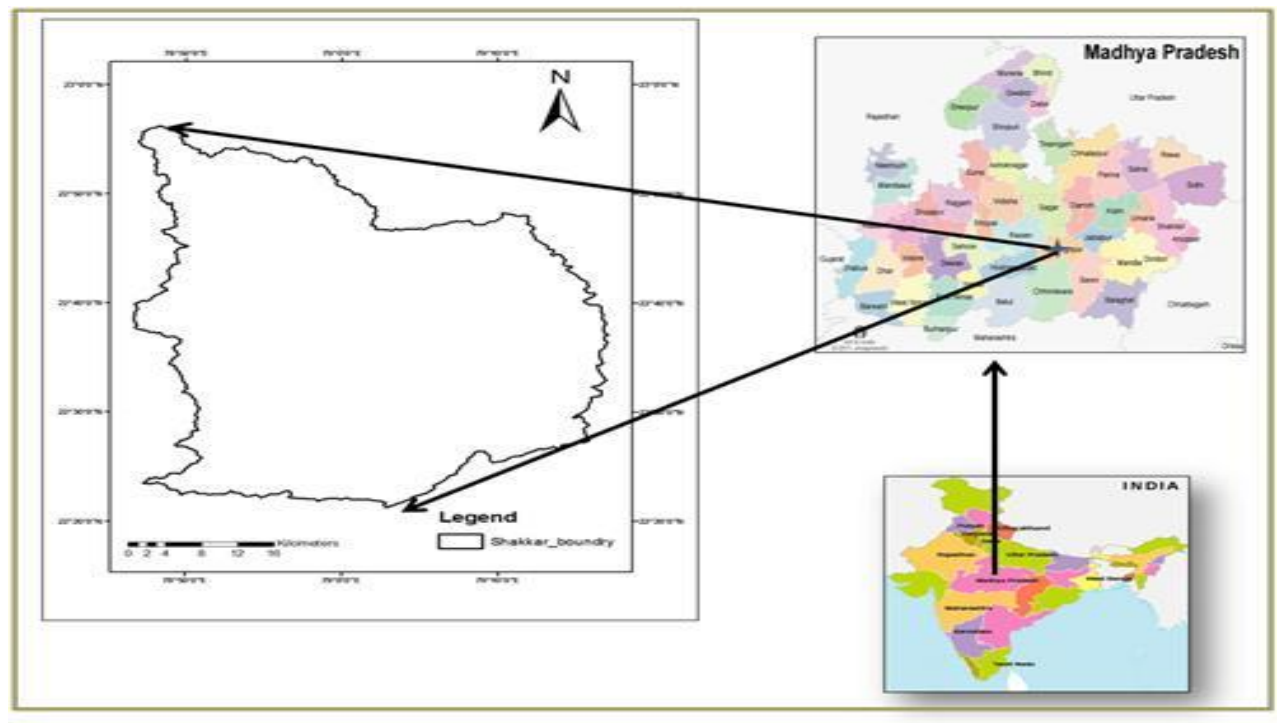

Figure 1. Location Map of the Study Area 


\section{Materials and Method}

Delineation of the Shakkar river catchment and preparation of drainage map (Figure 2) is based on geo-coded Digital Elevation Model (DEM) generated from Shuttle Radar Terrain Mapper (SRTM) data. The digitization of dendritic drainage pattern was carried out in GIS environment. The drainage network of the basin was analysed as per Horton's (1945) laws and the stream ordering was made after Strahler (1964). The sub-watersheds in the Shakkar river basin are shown in the Figure 3. In case of morphometric analysis, we have to assume in three aspects i.e., linear aspect, aerial aspect and relief aspect. Linear aspect is further divided into stream order $\left(\mathrm{N}_{\mathrm{u}}\right)$, stream length $(\mathrm{L})$ and bifurcation ratio $\left(\mathrm{R}_{\mathrm{b}}\right)$. Similarly aerial aspect divided into seven category drainage density $\left(D_{d}\right)$, stream frequency $\left(F_{s}\right)$, form factor $\left(R_{f}\right)$, circularity ratio $\left(R_{c}\right)$, elongation ratio $\left(R_{e}\right)$ and length overland flow $\left(L_{o}\right)$. Relief aspect is also divided into two category total relief $(M)$ and Relief ratio $\left(R_{r}\right)$ and Average slope $\left(S_{\mathrm{a}}\right)$. The formula for computation of the morphometric parameters is shown in Table 1.

\section{Software Used}

Arc view 3.1 power GIS software was used for creating, managing and generation of different layer and maps. The Microsoft excel was used for mathematical calculation (Gajbhiye and Mishra, 2012).

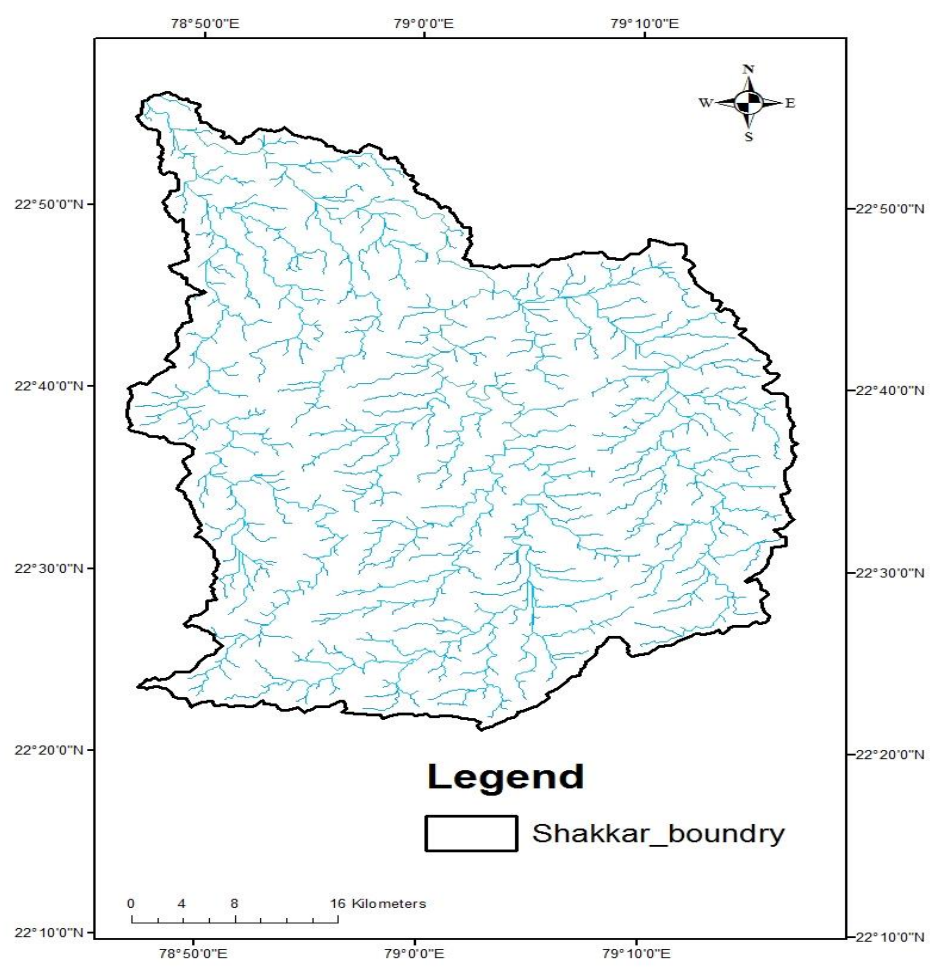

Figure 2. Drainage Map of the Study Area 


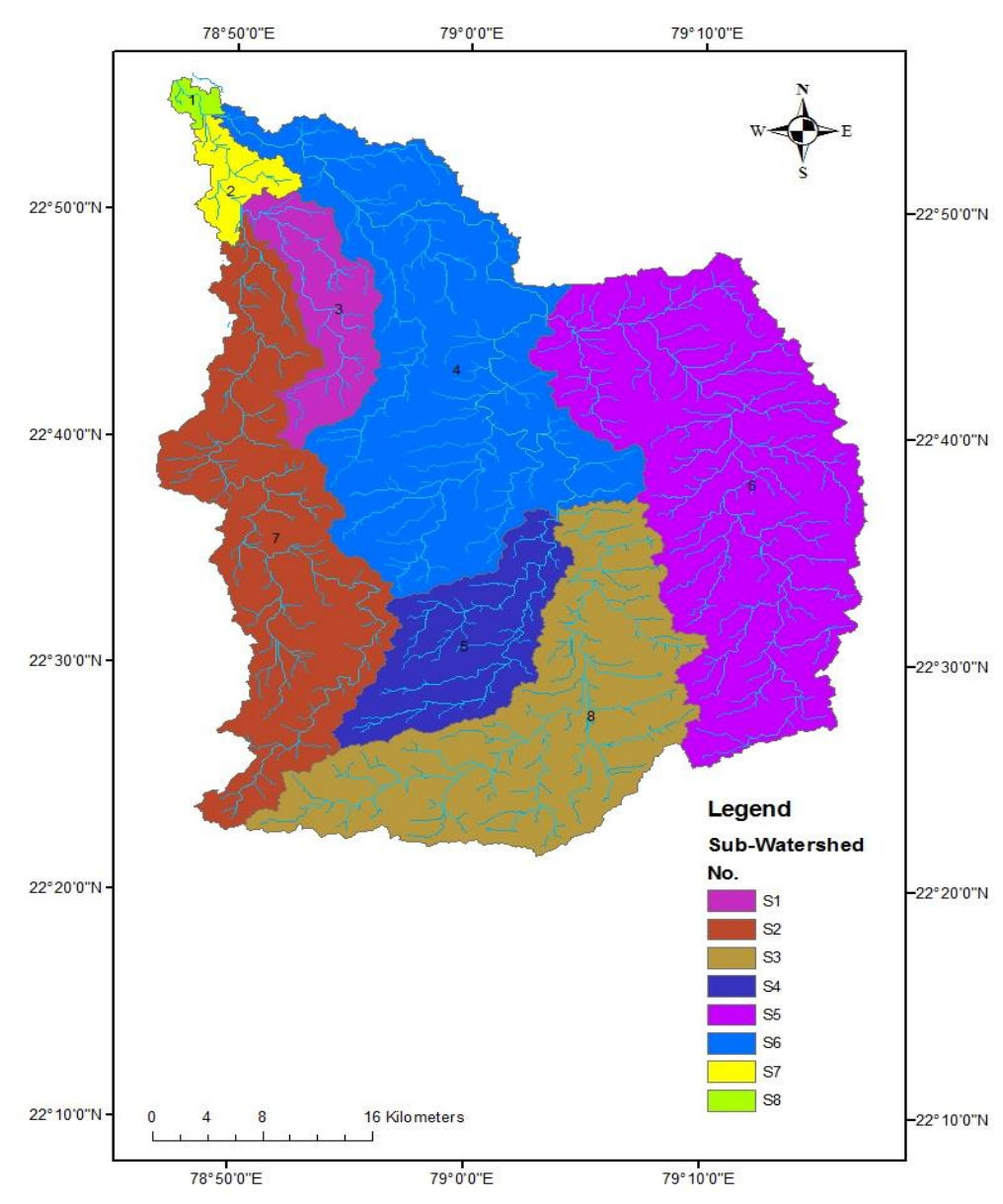

Figure 3. Sub- watershed of the Catchment

Table 1. Formula for Computation of Morphometric Parameters

\begin{tabular}{|l|l|l|}
\hline \multicolumn{1}{|c|}{$\begin{array}{c}\text { Morphometric } \\
\text { parameters }\end{array}$} & \multicolumn{1}{|c|}{ Formula } & Reference \\
\hline Stream Order $(\mathrm{u})$ & Hierarchical rank & Strahler (1964) \\
\hline $\begin{array}{l}\text { Stream Length }(\mathrm{Lu}) \\
\text { Length(Lsm) }\end{array}$ & $\begin{array}{l}\text { Length of the stream } \\
\text { Where, Lsm= Mean stream length } \\
\text { Lu= Total stream length of Order } \mathrm{u} \\
\text { Nu= Total number of stream segment of order } \\
\mathrm{u}\end{array}$ & Strahler (1964) \\
\hline $\begin{array}{l}\text { Bifurcation ratio } \\
\left(\mathrm{R}_{\mathrm{b}}\right)\end{array}$ & $\begin{array}{l}\mathrm{R}_{\mathrm{b}}=\mathrm{Nu} / \mathrm{N}_{\mathrm{u}+1} \\
\text { Where, } \mathrm{Rb}=\text { Bifurcation Ratio } \\
\text { Nu= Total number of stream segment of order }\end{array}$ & $\begin{array}{l}\text { Schumn } \\
(1956)\end{array}$ \\
\hline
\end{tabular}




\begin{tabular}{|c|c|c|}
\hline & $\begin{array}{l}\mathrm{u} \\
\mathrm{N}_{\mathrm{u}+1}=\text { Number of stream segment of next } \\
\text { higher order }\end{array}$ & \\
\hline $\begin{array}{l}\text { Mean Bifurcation } \\
\text { ratio }\left(\mathrm{R}_{\mathrm{bm}}\right)\end{array}$ & $\mathrm{R}_{\mathrm{bm}}=$ average of bifurcation ratio of all orders & Strahler (1964) \\
\hline Basin length $\left(\mathrm{L}_{\mathrm{b}}\right)$ & $\begin{array}{l}\mathrm{L}_{\mathrm{b}}=1.312 * \mathrm{~A}^{0.568} \\
\text { Where, } \mathrm{L}_{\mathrm{b}}=\text { length of basin }(\mathrm{km}) \\
\mathrm{A}=\text { area of Basin }\left(\mathrm{km}^{2}\right)\end{array}$ & $\begin{array}{l}\text { Nookaratnam } \\
\text { et.al (2005) }\end{array}$ \\
\hline $\begin{array}{l}\text { Drainage Density } \\
\left(D_{d}\right)\end{array}$ & $\begin{array}{l}D_{d}=L u / A \\
\text { Where, } D_{d}=\text { Drainage density } \\
\text { Lu= Total stream length of all order } \\
A=\text { Area of the basin }\end{array}$ & Horton (1945) \\
\hline $\begin{array}{l}\text { Stream Frequency } \\
\left(\mathrm{F}_{\mathrm{s}}\right)\end{array}$ & $\begin{array}{l}F_{s}=\mathrm{Nu} / \mathrm{A} \\
\text { Where, } \mathrm{Nu}=\text { Total number of stream of all } \\
\text { order } \\
\mathrm{A}=\text { Area of the basin }\left(\mathrm{km}^{2}\right)\end{array}$ & Horton (1945) \\
\hline Texture Ratio (T) & $\begin{array}{l}\mathrm{T}=\mathrm{Nu} / \mathrm{P} \\
\text { Where, } \mathrm{Nu}=\text { Total number of stream of all } \\
\text { order } \\
\mathrm{P}=\text { Perimeter }(\mathrm{km})\end{array}$ & Horton (1945) \\
\hline Form Factor $\left(\mathrm{R}_{\mathrm{f}}\right)$ & $\begin{array}{l}\mathrm{R}_{\mathrm{f}}=\mathrm{A} / \mathrm{L}_{\mathrm{b}}{ }^{2} \\
\text { Where, } \mathrm{Rf}=\text { Form factor } \\
\mathrm{A}=\text { area of the basin }\left(\mathrm{km}^{2}\right) \\
\mathrm{L}_{\mathrm{b}}{ }^{2}=\text { Square of the basin length }\end{array}$ & Horton (1945) \\
\hline $\begin{array}{l}\text { Circulatory Ratio } \\
\left(\mathrm{R}_{\mathrm{c}}\right)\end{array}$ & $\begin{array}{l}\mathrm{R}_{\mathrm{c}}=4 \pi \mathrm{A} / \mathrm{P}^{2} \\
\text { Where, } \mathrm{Rc}=\text { Circularity ratio } \\
\mathrm{A}=\text { Area of the basin }\left(\mathrm{km}^{2}\right) \\
\mathrm{P}=\text { Perimeter }(\mathrm{km})\end{array}$ & Miller (1953) \\
\hline $\begin{array}{l}\text { Elongation Ratio } \\
\left(\mathrm{R}_{\mathrm{e}}\right)\end{array}$ & $\begin{array}{l}\mathrm{R}_{\mathrm{e}}=\left(2 / \mathrm{L}_{\mathrm{b}}\right)^{*}(\mathrm{~A} / \pi)^{0.5} \\
\text { Where, } \mathrm{Re}=\text { Elongation Ratio } \\
\mathrm{L}_{\mathrm{b}}=\text { length of basin }(\mathrm{km}) \\
\mathrm{A}=\text { Area of the basin }\left(\mathrm{km}^{2}\right)\end{array}$ & $\begin{array}{l}\text { Schumn } \\
\text { (1956) }\end{array}$ \\
\hline
\end{tabular}




\begin{tabular}{|l|l|l|}
\hline Compactness & $\mathrm{C}_{\mathrm{c}}=0.2821 \mathrm{P} / \mathrm{A}^{0.5}$ & Horton (1945) \\
Constant $\left(\mathrm{C}_{\mathrm{c}}\right)$ & $\begin{array}{l}\text { Where, } \mathrm{Cc}=\text { Compactness Ratio } \\
\mathrm{A}=\text { Area of the basin }\left(\mathrm{km}^{2}\right) \\
\mathrm{P}=\text { Perimeter of the basin }(\mathrm{km})\end{array}$ & \\
\hline
\end{tabular}

\section{Analysis and Discussion}

The various morphometric parameters of the Shakkar river basin area were determined and are summarized in Tables 2-5. The basic parameter of the Shakkar River Catchment is shown in Table 1.

Table 2. Basic Parameter of the Shakkar River Catchment

\begin{tabular}{|c|c|c|c|c|}
\hline SW No. & SW Name & $\begin{array}{c}\text { Basin Area } \\
\left(\mathrm{Km}^{2}\right)\end{array}$ & Perimeter $(\mathrm{Km})$ & $\begin{array}{c}\text { Basin Length } \\
(\mathrm{Km})\end{array}$ \\
\hline 1 & S1 & 9.23 & 17.03 & 3.41 \\
\hline 2 & S2 & 37.87 & 41.11 & 9.00 \\
\hline 3 & S3 & 114.00 & 71.70 & 18.01 \\
\hline 4 & S4 & 538.22 & 171.78 & 43.00 \\
\hline 5 & S5 & 158.35 & 75.06 & 23.61 \\
\hline 6 & S6 & 581.45 & 150.45 & 36.89 \\
\hline 7 & S7 & 383.43 & 164.68 & 46.90 \\
\hline 8 & S8 & 397.96 & 131.84 & 25.27 \\
\hline
\end{tabular}

\subsection{Linear Aspects}

The linear aspects include the stream order $(\mathrm{u})$ and bifurcation ratio $\left(\mathrm{R}_{\mathrm{b}}\right)$ were determined and results have been presented in Table 3 .

\subsubsection{Stream Order (u)}

The first step in geomorphological analysis of a drainage basin is the designation of stream order, stream ordering as suggested by strahler (1964) was used for this study. Stream that originate at a source are defined as the first order stream. When two stream of first order join, an order two stream is created and so on. The order of a basin is the order of the highest stream. The streams up to six order can be seen in all the sub watersheds excepting sub- watershed 1,2 4. (Figure 2 and Table 3).

\subsubsection{Stream Number}

It is the number of stream segment of various order and is inversely proportional to the stream order. The number of the stream segments decreases as the order increases, the higher amount stream order indicates lesser permeability and infiltration. It is observed from the Table 3 that the maximum frequency is in case of first order streams. It is also noticed that there is a decrease in stream frequency as the stream order increases. 


\subsubsection{Stream Length ( Lu)}

The stream lengths of the various segments are measured with the help of GIS software. All the subwatersheds show that the total length of stream segments is maximum in first order streams and decreases as the stream order increases (Table$3)$.

\subsubsection{Bifurcation Ratio $\left(\mathbf{R}_{\mathrm{b}}\right)$}

It is the ratio of the number of streams of given order $u$ to the number of streams of higher order $u+1$. In general, lower value of $R_{b}$ is characteristics of watershed which has suffered less structural disturbances and the drainage pattern has not been distorted by structural disturbances (Nag and Chakroborty, 2003). Abnormally high value of $R_{b}$ might be expected in region of steeply dipping rock strata. The value of $R_{b}$ is also indicative of shape of the basin. An elongated basin is likely to have high $R_{b}$, where as a circular basin is likely to have a low $R_{b}$. Demonstrated that Bifurcation ratio shows a small range of variation for different regions or for different environment except where the powerful geological control dominates. It is observed from the Table 3, the Bifurcation ratio is not same from one to another. These irregularities are dependent upon the geological and lithological development of the drainage basin (Strahler, 1964). In the study area, the values of $\mathrm{R}_{\mathrm{b}}$ vary from 3.49 to 5.52 (Table 3 ).

Table 3. Linear Aspect of the Shakkar River Catchment

\begin{tabular}{|c|c|c|c|c|c|c|c|c|c|}
\hline \multirow[t]{2}{*}{ Sub-watershed } & \multicolumn{8}{|c|}{ Stream Order } & \multirow{2}{*}{$\begin{array}{l}\text { Mean } \\
\text { Bifurcation } \\
\text { Ratio }\left(\mathbf{R}_{\mathbf{b}}\right)\end{array}$} \\
\hline & $\mathrm{I}$ & II & III & IV & $\mathrm{V}$ & VI & VII & VIII & \\
\hline \multicolumn{10}{|l|}{ Sub-watershed-1 } \\
\hline No. of Stream & 58 & 13 & 2 & 0 & 0 & 0 & 2 & 1 & \multirow{2}{*}{3.49} \\
\hline Stream Length $(\mathrm{km})$ & 20.98 & 6.26 & 2.34 & 0 & 0 & 0 & 0.098 & 4.23 & \\
\hline \multicolumn{10}{|l|}{ Sub-watershed-2 } \\
\hline No. of Stream & 209 & 49 & 14 & 2 & 0 & 2 & 1 & 0 & \multirow{2}{*}{3.55} \\
\hline Stream Length $(\mathrm{km})$ & 66 & 30 & 16 & 6 & 0 & 0.097 & 10 & 0 & \\
\hline \multicolumn{10}{|l|}{ Sub-watershed-3 } \\
\hline No. of Stream & 590 & 125 & 29 & 7 & 2 & 1 & 0 & 0 & \multirow{2}{*}{3.73} \\
\hline Stream Length $(\mathrm{km})$ & 163 & 83 & 38 & 12 & 24 & 4.37 & 0 & 0 & \\
\hline \multicolumn{10}{|l|}{ Sub-watershed-4 } \\
\hline No. of Stream & 2992 & 646 & 138 & 28 & 5 & 3 & 1 & 0 & \multirow{2}{*}{4.30} \\
\hline Stream Length $(\mathrm{km})$ & 867 & 411 & 185 & 72 & 58.12 & 0.18 & 75.66 & 0 & \\
\hline \multicolumn{10}{|l|}{ Sub-watershed-5 } \\
\hline No. of Stream & 913 & 211 & 52 & 8 & 2 & 1 & 0 & 0 & \multirow{2}{*}{4.17} \\
\hline Stream Length $(\mathrm{km})$ & 246 & 121 & 52 & 40 & 20 & 7.36 & 0 & 0 & \\
\hline
\end{tabular}




\begin{tabular}{|c|c|c|c|c|c|c|c|c|c|}
\hline Sub-watershed-6 & & & & & & & & & \\
\hline No. of Stream & 3237 & 715 & 164 & 45 & 11 & 1 & 0 & 0 & \multirow{2}{*}{5.52} \\
\hline Stream Length $(\mathrm{km})$ & 961 & 433 & 237 & 108 & 50 & 48.83 & 0 & 0 & \\
\hline \multicolumn{10}{|l|}{ Sub-watershed-7 } \\
\hline No. of Stream & 2165 & 463 & 117 & 25 & 3 & 1 & 0 & 0 & \multirow{2}{*}{4.93} \\
\hline Stream Length $(\mathrm{km})$ & 633 & 286 & 127 & 71 & 29 & 42.68 & 0 & 0 & \\
\hline \multicolumn{10}{|l|}{ Sub-watershed-8 } \\
\hline No. of Stream & 2340 & 544 & 125 & 29 & 5 & 1 & 0 & 0 & \multirow{2}{*}{4.75} \\
\hline Stream Length $(\mathrm{km})$ & 662 & 279 & 154 & 87 & 30 & 40.37 & 0 & 0 & \\
\hline
\end{tabular}

\subsection{Areal Aspects}

Area of a basin (A) and perimeter $(\mathrm{P})$ are the important parameters in quantitative geomorphology. The area of the basin is defined as the total area projected upon a horizontal plane. Perimeter is length of the boundary of the basin. Areal aspects include different morphometric parameters, like drainage density $\left(D_{d}\right)$, stream frequency $\left(F_{s}\right)$, form factor $\left(R_{f}\right)$, circulatory ratio $\left(R_{c}\right)$, elongation ratio $\left(R_{e}\right)$ and length of the overland flow $\left(\mathrm{L}_{\mathrm{o}}\right)$. The values of these parameters were calculated and results have been given in Table 4.

\subsubsection{Drainage Density $\left(D_{d}\right)$}

Drainage density is one of the important indicators of the linear scale of land form in a stream eroded topography, and is defined as the ratio of total length of the streams of all order of basin to the area of basin. The drainage density, expressed in $\mathrm{km} / \mathrm{km}^{2}$, indicates closeness of spacing of channels, thus providing a quantitative measure of the average length of stream channel for the whole basin. Further, it also gives an idea of the physical properties of the underlying rocks. Low drainage density occurs in regions of highly resistant and permeable sub soil materials with dense vegetation and low relief, where as high drainage density is prevalent in region of weak, impermeable sub surface material which is sparsely vegetated and have high relief (Strahler1964). Drainage density in the study are varies between 2.84 and 3.67 indicating low drainage density (Table-4). According to Nag (1998), low drainage density generally results in the areas of highly resistant on permeable subsoil material, dense vegetation, low relief and coarse drainage texture. High drainage density is resultant of weak or impermeable subsurface material, sparse vegetation, mountainous relief and fine drainage texture.

\subsubsection{Stream frequency /Drainage Frequency $\left(F_{s}\right)$}

Stream frequency is the number of streams per unit area of the basin. It mainly depend upon the lithology of the basin and reflects the texture of the drainage network. The low value of 6.61 observed in sub-watershed-3, while high value of 8.23 observed in sub-watershed-1.Increase in stream population with respect to increase in drainage density has been noticed in all sub-watersheds. 


\subsubsection{Form Factor $\left(R_{f}\right)$}

It is the ratio of basin area $\mathrm{A}$, to the square of maximum length of the basin $\mathrm{L}_{\mathrm{b}}$. It is dimensionless property and is use as a quantitative expression of the shape of basin form. Lower values of form factor are observed in sub-watershed-7 leads to circular in shape.

\subsubsection{Circulatory Ratio $\left(R_{c}\right)$}

It is the ratio of the watershed area and the area of circle of watershed perimeter (Pr). Same perimeters as that of the basin. Values of circulatory ratio of all sub watersheds are presented in Table 4 . The sub-watershed-7 has minimum value 0.17 while sub-watershed-1 has maximum value 0.40 .

\subsubsection{Elongation Ratio $\left(R_{\mathrm{e}}\right)$}

It is defined as the ratio between the diameter of a circle with the same area that of the basin to the maximum length of the basin. The elongation ratio ranges from 0.0 to 1.0 over a wide variety of climatic and geological environments. Value nearing 1 are typical of regions of low relief, whereas value in the range of $0.6-0.8$ are generally associated with strong relief and steep ground slopes. Elongated basin with high bifurcation ratio yield a low but extended peak flow (Verstappen, 1983). The lowest values of 0.47 (sub-watershed-7) and 1 (sub-watershed-1) indicate high relief and steep slopes, while remaining sub-watershed indicates that plain land with low relief and low slope.

\subsubsection{Length of Overland Flow $\left(\mathrm{L}_{\mathrm{o}}\right)$}

It is defined as the ratio between the diameter of a circle with the same area that of the basin to the maximum length of the basin. The elongation ratio ranges from 0.0 to 1.0 over a wide variety of climatic and geological environments. Value nearing 1 are typical of regions of low relief, whereas value in the range of $0.6-0.8$ are generally associated with strong relief and steep ground slopes. Elongated basin with high bifurcation ratio yield a low but extended peak flow (Verstappen, 1983). The lowest values of 0.47 (sub-watershed-7) and 1 (sub-watershed-1) indicate high relief and steep slopes.

Table 4. Aerial Aspect of the Shakkar River Catchment

\begin{tabular}{|c|c|c|c|c|c|c|c|c|c|}
\hline $\begin{array}{c}\text { Sub- } \\
\text { Water } \\
\text { shed }\end{array}$ & $\begin{array}{c}\text { Drainage } \\
\text { Density } \\
\left(\mathrm{D}_{\mathrm{d}}\right)\end{array}$ & $\begin{array}{c}\text { Stream } \\
\text { Frequenc } \\
\mathrm{y}\left(\mathrm{F}_{\mathrm{s}}\right)\end{array}$ & $\begin{array}{c}\text { Circulato } \\
\text { ry Ratio } \\
\left(\mathrm{R}_{\mathrm{c}}\right)\end{array}$ & $\begin{array}{c}\text { Form } \\
\text { Factor } \\
\left(\mathrm{R}_{\mathrm{f}}\right)\end{array}$ & $\begin{array}{c}\text { Elongati } \\
\text { on Ratio } \\
\left(\mathrm{R}_{\mathrm{e}}\right)\end{array}$ & $\begin{array}{c}\text { Texture } \\
\text { Ratio } \\
(\mathrm{T})\end{array}$ & $\begin{array}{c}\text { Length } \\
\text { of } \\
\text { overland } \\
\text { flow }\left(\mathrm{L}_{\mathrm{o}}\right)\end{array}$ & $\begin{array}{c}\text { Compa } \\
\text { ctness } \\
\text { Consta } \\
\mathrm{nt}\left(\mathrm{C}_{\mathrm{c}}\right)\end{array}$ & $\begin{array}{c}\text { Ruggedn } \\
\text { ess } \\
\text { Number } \\
\left(\mathrm{R}_{\mathrm{N}}\right)\end{array}$ \\
\hline 1 & 3.673 & 8.232 & 0.403 & 0.794 & 1.006 & 4.464 & 0.136 & 0.126 & 0.147 \\
\hline 2 & 3.383 & 7.315 & 0.283 & 0.468 & 0.772 & 6.739 & 0.148 & 0.048 & 0.203 \\
\hline 3 & 2.845 & 6.614 & 0.281 & 0.351 & 0.669 & 10.516 & 0.176 & 0.021 & 1.682 \\
\hline 4 & 3.101 & 7.085 & 0.231 & 0.291 & 0.609 & 22.197 & 0.161 & 0.007 & 1.896 \\
\hline 5 & 3.071 & 7.496 & 0.356 & 0.284 & 0.602 & 15.815 & 0.163 & 0.015 & 1.659 \\
\hline 6 & 3.161 & 7.177 & 0.325 & 0.427 & 0.738 & 27.738 & 0.158 & 0.006 & 1.865 \\
\hline 7 & 3.100 & 7.235 & 0.179 & 0.174 & 0.471 & 16.845 & 0.161 & 0.009 & 2.483 \\
\hline 8 & 3.147 & 7.649 & 0.290 & 0.623 & 0.891 & 23.088 & 0.159 & 0.008 & 1.825 \\
\hline
\end{tabular}




\subsection{Relief Aspects}

Relief aspects of drainage basin relate to the three dimensional features of the basin involving area, volume and altitude of vertical dimension of landforms wherein different morphometric methods are used to analyse terrain characteristics. In this study, thus, relief aspect includes the analysis of average slope, relative reliefs, etc.

\subsubsection{Total Relief $(M)$}

It is the maximum vertical distance between the lowest and highest point of the watershed. It is also known as maximum watershed relief $(\mathrm{H})$.

\subsubsection{Relief Ratio $\left(\mathbf{R}_{\mathrm{h}}\right)$}

The relief ratio defined as the ratio between the total relief of a basin and the longest dimension of the basin parallel to the main drainage line (Schumm,1956). In the study area, the values of relief ratio vary from 0.001 to 0.008 (Table 5). It has been observed that areas with high relief and steep slope are characterized by high value of relief ratios. Low value of relief ratios are mainly due to the resistant basement rocks of the basin and low degree of slope.

\subsubsection{Average Slope $\left(S_{a}\right)$}

Average slope of the watershed, $S_{a}$ has direct influence on the erodibility of the watershed. It has been proved by researcher that more the percentage of slope more is the erosion, if other factors remain unchanged. The values of Average slope vary from 9.27 to $88.50 \%$ (Table 5).

\subsubsection{Relative Relief $\left(R_{r}\right)$}

It is the ratio of the maximum watershed relief to the perimeter of the watershed. The value of the relative relief for 8 sub watershed is shown in Table 5. Sub watershed 2 has minimum $\mathrm{R}_{\mathrm{r}}(0.007)$, while sub watershed 3 had the maximum value $(0.030)$.

Table 5. Relief Aspect of the Shakkar River Catchment

\begin{tabular}{|c|c|c|c|}
\hline Sub-Watershed & $\begin{array}{c}\text { Relative Relief } \\
(\mathrm{Rh})\end{array}$ & $\begin{array}{c}\text { Relief Ratio } \\
(\mathrm{Rr})\end{array}$ & $\begin{array}{c}\text { Average Slope (Sa) } \\
\%\end{array}$ \\
\hline 1 & 0.012 & 0.002 & 30.526 \\
\hline 2 & 0.007 & 0.001 & 9.277 \\
\hline 3 & 0.030 & 0.008 & 11.017 \\
\hline 4 & 0.014 & 0.003 & 27.563 \\
\hline 5 & 0.023 & 0.007 & 88.505 \\
\hline 6 & 0.016 & 0.004 & 27.588 \\
\hline 7 & 0.017 & 0.005 & 50.655 \\
\hline 8 & 0.023 & 0.004 & 38.312 \\
\hline
\end{tabular}

\section{Conclusion}

Quantitative analysis of drainage network found the dendritic to sub dendritic drainage pattern due to changes in slope and topography with six order streams in all 
sub-watersheds except sub-watershed 1, 2 and 4. The variation in values of bifurcation ratio among the sub-watersheds is ascribed to the difference in topography and geometric development. Drainage density is very coarse to coarse texture. The development of stream segments is affected by slope and local relief (Strahler, 1964) the physiographic structure of the basin area produces high surface runoff values and low infiltration rates. The conventional methods of morphometric analysis are time consuming, tiresome and error prone, while use of GIS technique allows for more reliable and accurate estimation of similar parameters of watersheds. The morphometric analysis of different sub watersheds shows their relative characteristics with respect to hydrologic response of the watershed.

\section{References}

[1] Agarwal, C.S., Study of drainage pattern through aerial data in Naugarh area of Varanasi district, U.P, Journal of Indian Society of Remote Sensing, 26, 169-175, (1998).

[2] ArcGIS, GIS software, version 9.2, Environmental Systems Research Institute (ESRI), New York, (2006).

[3] Biswas, S., Sudhakar, S., and Desai, V.R., Prioritisation of sub-watersheds based on Morphometric analysis of drainage basin-a remote sensing and GIS approach, Journal of Indian Society of Remote Sensing, 27,155-166, (1999).

[4] Chorley, R.J., Donald, E.G., Malm. and Pogorzelski, H.A., A new standard for estimating drainage basin shape, American Journal Science, 225, 138-141, (1957).

[5] Chow, V.T., Handbook of Applied Hydrology. McGraw-Hill, New York, (1964).

[6] Das, A. K. Mukherjee, Saumitra, Drainage morphometry satellite data and GIS in Raigad District, Maharashtra, Journal of Geological Society of India, 65, 577-586, (2005).

[7] ERDAS IMAGINE, Digital Image Processing Software, Version 9.2, Leica Geosystems \& GIS Mapping, Atlanta, U.S.A., (2008).

[8] Gajbhiye, S. and Mishra, S.K., Application of NRSC-SCS Curve Number Model in Runoff Estimation Using RS \& GIS, IEEE-International Conference on Advances in Engineering Science and Management (ICAESM -2012) March 30-31, pp 346-352, (2012).

[9] Gajbhiye, S., Mishra, S.K. and Pandey, A., Prioritization of Shakkar River catchment through Morphometric Analysis using Remote Sensing and GIS techniques. Journal of Emerging Technology in Mechanical Science and Engineering, 4(2), 129-142, (2013a).

[10] Gajbhiye, S., Mishra, S.K. and Pandey, A., Effect of seasonal/monthly variation on runoff Curve Number for selected watersheds of Narmada Basin. International Journal of Environmental Sciences, 3(6), 20192030, (2013b).

[11] Gajbhiye, S., Mishra, S.K. and Pandey, A., Prioritizing erosion-prone area through morphometric analysis: an RS and GIS perspective. Applied Water Science, 4(1), 51-61, (2013c).

[12] Gajbhiye, S., Mishra, S.K. and Pandey, A., Simplified sediment yield index model incorporating parameter. Arabian Journal of Geosciences, 1-12, doi; 10.1007/s12517-014-1319-9 (2014a).

[13] Gajbhiye, S., Mishra, S.K. and Pandey, A., Relationship Between SCS-CN and Sediment Yield. Applied Water Science, 4(4), 363-370, (2014b).

[14] Gajbhiye, S., Mishra, S.K. and Pandey, A., Hypsometric Analysis of Shakkar River Catchment through Geographical Information System. Journal of the Geological Society of India, 84, 192-196, (2014c)

[15] Gajbhiye, S., Sharma, S.K. and Meshram, C., Prioritization of Watershed through Sediment Yield Index Using RS and GIS Approach. International Journal of u- and e- Service, Science and Technology, 7(6), 47-60, (2014d).

[16] Horton, R.E., Drainage basin characteristics, Transactions of American Geophysical Association, 13, 350-361, (1932).

[17] Horton, R.E., Erosional development of streams and their drainage basins: Hydrophysical approach to quantitative morphology, Geological society of America Bulletin, 5, 275-370, (1945).

[18] Jensen, J.R., Remote Sensing of the Environment, Dorling Kindersley (India) Pvt. Ltd., New Delhi, $1^{\text {st }}$ edition, (2006).

[19] Langbein, W.B., Topographic characteristics of drainage basins, U.S. Geol. Survey, Water-Supply paper, 986(C), 157-159, (1947).

[20] Miller, V.C., A quantitative geomorphic study of drainage basin characteristics in the Clinch Mountain area, Varginia and Tennessee, Project NR 389042, Tech. Rept.3., Columbia University, Department of Geology, ONR, Geography Branch, New York, (1953).

[21] Mishra, S.K., Gajbhiye, S., Pandey, A., Estimation of design runoff curve numbers for Narmada watersheds (India), Journal of Applied Water Engineering and Research, 1(1), 69-79, (2013).

[22] Nag, S.K., Morphometric analysis using remote sensing techniques in the Chaka sub-basin Purulia district, West Bengal, Journal of Indian Society of Remote Sensing, 26, 69-76, (1998). 
[23] Nageswara Rao, K., Swarna Latha. P, Arun Kumar P., and Hari Krishna.M., Morphometric Analysis of Gostani River Basin in Andhra Pradesh State, India Using Spatial Information Technology, International Journal of Geomatics and Geosciences, 1, 179-187, (2010).

[24] Narendra, K., and Nageswara Rao, K., Morphometry of the Mehadrigedda watershed, Visakhapatnam district, Andhra Pradesh using GIS and Resourcesat data, Journal of Indian Society of Remote Sensing, 34, 101-110, (2006).

[25] Reddy, Gangalakunta P., Obi, Maji, Amal K., Gajbhiye, Kothiram S., Drainage morphometry and its influence on landforms characteristics in a basaltic terrain, central India- a remote sensing and GIS approach, International Journal of Applied Observation and Geoinformation, 6, 1-16, (2004).

[26] Schumn, S.A., Evaluation of drainage systems and slopes in badlands at Perth Amboy, New Jersy, Geological Society of America bulletin, 67, 597-646, (1956).

[27] Sharma, S.K., Yadav, A. and Gajbhiye, S. Remote Sensing and GIS Approach for Prioritization of Watershed, LAMBERT Academic Publishing, Germany, ISBN 978-3-659-53529-1, (2014).

[28] Singh, S., Physical Geography, Prayag Pustak Bhawan, Allahabad, India, (1998).

[29] Singh, S., and Singh, M.C., Morphometric analysis of Kanhar river basin. National Geographical Journal of India, 43(1), 31-43, (1997).

[30] Smith, K.G., Standards for grading texture of erosional topography, American Journal Science, 248, 655668, (1950).

[31] Srivastava, V.K., and Maitra, D., Study of drainage pattern of Raniganj Coalfield (Burdwan District) as observed on Landsat-TM/IRS LISS II imagery, Journal of Indian Society of Remote Sensing, 23, 225-235, (1995).

[32] Strahler, A.N., Strahler, A.H., a Text Book of Physical Geography, John Wiley \& Sons, New York, (2002).

[33] Strahler, A.N., Quantative analysis of watershed geomorphology, Transactions of American Geophysical Union, 38, 913-920, (1957).

[34] Strahler, A.N., Quantitave geomorphology of drainage basins and channel networks In. Handbook of Applied Hydrology, McGraw Hill Book Company, New York, Section 4-II, (1964).

[35] Thakur, V.C. and Pandey, A.K., Late Quaternary tectonic evolution of Dun in fault Bend /propagated fold system, Garhwal Sub-Himalaya, Current Science, 87 (11), 1567-1576, (2004).

\section{Author}

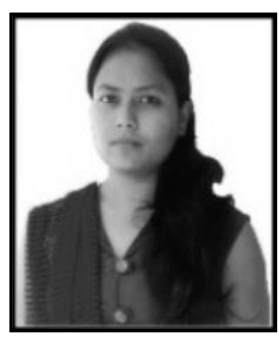

Sarita Gajbhiye, the author was born on $8^{\text {th }}$ June 1986 at Chhindwara, Madhya Pradesh. She received her B.Tech degree (Agricultural Engineering) in 2007 and M.Tech degree (Soil and Water Engineering) gold medal in 2009, both from College of Agricultural Engineering, J.N.K.V.V., Jabalpur (M.P.). She is currently a PhD student in the Department of Water Resource Development and Management, IIT, Roorkee (Uttarakhand) India. She was awarded UGC scholarship for P.G Programme and DST INSPIRE fellowship for Ph.D Programme. Her current research interests include Morphometric Analysis, Rainfall-Runoff, Sediment Yield, Water Quality Modeling using PCA approach, RS and GIS Applications in Hydrology, Hydrological Modelling, Soil and Water Conservation Engineering. 3 book, 20 research paper in National and International Journals, 10 papers in National and International conferences at her credit. She is a member of Science and Engineering Institute (SCIEI), Asian Association for Agricultural Engineering (AAAE), International Association of Engineers (IAENG, Hong Kong), World Academy of Science, Engineering and Technology (WASET, Newzealand). Student Member, American Society of Civil Engineers (ASCE), Academic journal online (Editorial Board member of management), American Society of Civil Engineers (ASCE), A Water and Enviro Modeling Group (AWEM), International Society for Agricultural Meteorology, International journal of Applied Science (Editorial board member), International Journal of Engineering Trends and Technology (Editorial board member), 
International Association of Hydrological Sciences, International Commission on Statistical Hydrology, Blue Eyes Intelligence Engineering \& Sciences Publication all Journal (Editorial board member). 
International Journal of $u-$ and $e-$ Service, Science and Technology Vol.8, No.2 (2015) 